\title{
全反射型赤外分光法による血糖值の測定
}

\author{
唐 津 孝 ${ }^{1}$, 岩田 大輔 $^{1}$, 中嶋 俊晴 ${ }^{1}$, 矢貝 史樹 ${ }^{1}$, \\ 清宮 正徳 ${ }^{2}$ ，野村 文夫 ${ }^{2}$ ，北村 彰英 ${ }^{\circledR 1}$
}

\section{Determination of the Glucose in Serum by the FT-IR-ATR Method}

\author{
Takashi Karatsu $^{1}$, Daisuke Imata ${ }^{1}$, Toshiharu NakajIma ${ }^{1}$, Shiki Yagai ${ }^{1}$, \\ Masanori SEImIYA $^{2}$, Fumio Nomura ${ }^{2}$ and Akihide Kitamura ${ }^{1}$
}

\footnotetext{
${ }^{1}$ Department of Applied Chemistry and Biotechnology, Faculty of Engineering, Chiba University, 1-33, Yayoicho, Inage-ku, Chiba-shi, Chiba 263-8522

${ }^{2}$ Graduate School of Medicine, Chiba University, 1-8 - 1, Inohana, Chuo-ku, Chiba-shi, Chiba 260 - 8677
}

(Received 13 September 2004, Accepted 3 October 2004)

\begin{abstract}
The development of instant determinations of glucose has attracted much attention from the viewpoint of diabetic treatment. We propose a determination by using FT-IR with an attenuated total-reflection method (ATR). However, it is not easy to obtain accurate values of the concentrations of glucose in serums. In order to obtain a high correlation coefficient $(R)$ between the concentrations obtained by the FT-IR-ATR method and those obtained by the enzyme method, we improved the method, for example, by changing the shape of the sample holder, and developed an extraction method of the absorption band from the background by using of a second-ordered differential method. Finally, we obtained $R=0.807$, which opened a possibility of using the FT-IR-ATR method for the instant determination of glucose.
\end{abstract}

Keywords : glucose ; serum ; FT-IR ; ATR.

\section{1 緒言}

近年の成人病患者の増加や社会の高齢化に伴い，診断医 療の重要性がますます高まっている，治療を行うに当たっ ては，まず体内成分についての検査が必要であり，中でも 血液検查は得られる情報量から非常に重要な位置を占めて いる，しかしながら，現行の血液検查では，注射針などを 用いて採取した血液をそれぞれの成分を検出する試薬と反 応させて, 血液成分の定量を行っている。このように現在 の血液検査では成分ごとに異なった試薬を必要とするの で, 操作が煩雑で, 結果が出るまでに相応の時間が必要と される. また, 1 回の測定にかかるコストも無視できない.

\footnotetext{
${ }^{1}$ 千葉大学工学部共生応用化学科 : 263-8522 千葉県千葉市稲毛 区弥生町 1-33

2 千葉大学大学院医学研究院分子病態解析学 - 同付属病院検査 部: 260-8677 千葉県千葉市中央区亥鼻 1-8-1
}

更に採血は被験者，特に高齢者や幼児などの身体に負担が かかると同時に感染のリスクも伴う。これらの問題を解決 するために，非侵襲で簡便な測定方法の開発が望まれてい る.そのひとつの候補として全反射型プリズム（ATR）法 を用いたフーリエ変換赤外分光法がある ${ }^{1)}$.この方法は, 試料とプリズムの境界面で光を全反射させ，全反射する際 に試料内部へわずかに潜り込んで反射するエバネッセント 光を測定することで試料表層の赤外吸収スペクトルを得る 方法であり，非侵襲での測定が期待される。しかしなが ら，生体成分は複雑で，赤外吸収スペクトルによる定量は 極めて困難なのが現状である.

我が国に抢ける糖尿病患者は増加の一途をたどり，現 在，40 歳以上の 10 人にひとりが糖尿病の治療が必要であ り，その背後にはほほ同数の糖尿病予備軍が控えている.

今回，糖尿病診療の場で頻繁に測定されるグルコース濃 度を，血清を用いて赤外吸収スペクトルにより定量するこ 
Table 1 Labotatory data of serum samples $(\mathrm{g} / \mathrm{l})$

\begin{tabular}{|c|c|c|c|c|c|c|c|}
\hline Sample & Total proteins & Albumin & Creatinine & Uric acid & Urea & Glucose & Total cholesterols \\
\hline No. 1 & 46 & 18 & 0.0042 & 0.018 & 0.04 & 0.85 & 0.82 \\
\hline No. 2 & 75 & 42 & 0.0133 & 0.0095 & 0.31 & 1.23 & 1.63 \\
\hline No. 3 & 62 & 39 & 0.1284 & 0.078 & 0.67 & 1.83 & 1.47 \\
\hline No. 4 & 47.4 & 22.7 & - & - & - & 1.05 & 1.04 \\
\hline No. 5 & 70 & 43 & 0.006 & 0.047 & 0.124 & 0.95 & 1.84 \\
\hline No. 6 & 72 & 38 & 0.007 & 0.062 & 0.15 & 2.52 & 2.43 \\
\hline No. 7 & 75 & 42 & 0.013 & 0.095 & 0.31 & 1.23 & 1.63 \\
\hline No. 8 & 66 & 41 & 0.005 & 0.055 & 0.14 & 0.81 & 1.62 \\
\hline No. 9 & 68 & 44 & 0.006 & 0.027 & 0.1 & 1.46 & 2.39 \\
\hline No. 10 & 80 & 46 & 0.005 & 0.052 & 0.14 & 0.8 & 2.42 \\
\hline No. 11 & 71 & 47 & 0.005 & 0.033 & 0.18 & 0.77 & 2.34 \\
\hline No. 12 & 76 & 45 & 0.01 & 0.049 & 0.34 & 1.1 & 1.7 \\
\hline No. 13 & 62 & 39 & 0.128 & 0.078 & 0.67 & 1.83 & 1.47 \\
\hline No. 14 & 76 & 47 & 0.059 & 0.026 & 0.26 & 1.05 & 1.47 \\
\hline No. 15 & 38 & 23 & - & 0.068 & 0.282 & 0.71 & 3.01 \\
\hline No. 16 & 64.6 & 39.6 & - & 0.04 & 0.097 & 0.83 & 1.79 \\
\hline No. 17 & 85.6 & 41.5 & - & 0.044 & 0.13 & 0.71 & 2.6 \\
\hline No. 18 & 68 & 38 & - & - & - & 0.7 & 2.3 \\
\hline No. 19 & 67 & 43 & - & - & - & 3.63 & 1.93 \\
\hline No. 20 & 73 & 41 & - & - & - & 2.52 & 1.99 \\
\hline No. 21 & 71 & 37 & - & - & - & 1.05 & 1.67 \\
\hline
\end{tabular}

とを試みた。

$$
2 \text { 実験 }
$$

\section{$2 \cdot 1$ 測定装置及び試料}

赤外分光光度計は日本分光製 FT/IR-410 用い, ATR として PIKE Technologies 製 MIRacle ${ }^{\mathrm{TM}}$ ダイアモンド 2 回 反射 HATR (diamond dual-reflection horizontal ATR) を 用いた。測定は積算回数 256 回, 分解能 $1 \mathrm{~cm}^{-1}$ で行っ た。

血清並びに総タンパク質標準溶液は千葉大学医学部付属 病院検査部から提供を受け, $D-(+)$-glucose は和光純薬の 市販品をそのまま用いた。

測定に使用した血清の成分を Table 1 にまとめる.

\section{$2 \cdot 2$ 溶液状態の血清の赤外吸収スペクトルの測定}

$30 \mu \mathrm{l}$ の血清（No. 1, No. 2, No. 3, No. 4）及び総夕ン パク質の標準溶液（総タンパク質濃度 $=8.0 \mathrm{~g} / \mathrm{l}$ ）を溶液 状態のまま, ATR プリズム上に滴下し, 赤外吸収スペク トルを測定した。各血清は 5 回ずつ, 総タンパク質の標 準溶液は 1 回測定を行った.

\section{$2 \cdot 3$ 乾燥させた血清の赤外吸収スペクトルの測定}

乾燥試料の調製及び測定は, 以下の 2 種類の方法によ った。

方法 1) : No. 5 の血清 $(0.95 \mathrm{~g} / \mathrm{l}) 5 \mathrm{ml}$ に $33.25 \mathrm{mg}$ のグ ルコースを加え, $7.60 \mathrm{~g} / 1$ の試料を得た。 その溶液 $2 \mathrm{ml}$ にNo. 5 の血清 $2 \mathrm{ml}$ を加え, $4.28 \mathrm{~g} / 1$ の試料を得た. 同様 の操作を繰り返し， $2.61 \mathrm{~g} / 1$ と $1.78 \mathrm{~g} / 1$ の試料を調製し,
次のように乾燥した。試料 $30 \mu \mathrm{l}$ を ATR プリズム上に滴 下し，室温で放置することにより乾燥した。乾燥の程度は スペクトルの経時変化で調べた。スペクトル変化が見られ なくなった 5 時間後を乾燥の終了とし，各々の試料につ き 3 回，IRを測定した。また，No. 6 から No. 14の 9 種 類の血清のみを乾燥した後，各々の血清につき 3 回，測 定した。

方法 2) : No. 15 の血清 $(0.71 \mathrm{~g} / \mathrm{l})$ を $180 \mu \mathrm{l}$ ずつ 4 つの バイアルに分取し，それぞれにグルコース濃度が $0,4.55$, $9.11,18.21 \mathrm{~g} / 1$ の溶液 $20 \mu \mathrm{l}$ を加えて，グルコース濃度が それぞれ $0.64,1.09,1.55,2.46 \mathrm{~g} / 1$ の 4 種類の試料を得 た. 同様の操作を総タンパク質濃度の大きく異なる他の血 清（No. 16, No.17）でも行った.

これらの試料を次の方法で乾燥させた。溶液状態の血清 $30 \mu \mathrm{l}$ をATR プリズム上に滴下し, HATR アタッチメント ごとデシケーター内に入れ， $20 \mathrm{mmHg}$ で 20 分間減圧乾 燥した。減圧乾燥時間を延長すると試料がプリズムから剥 離するため, その後自然乾燥した. 赤外分光器にアタッチ メントをセットし，スペクトルを５分間隔で測定したと ころ, 30 分後には $1000 \mathrm{~cm}^{-1}$ 付近の吸光度が最も大きく なり, また変化しなくなったため, その時点で定量測定を 行った.

以上の 12 種類の試料を，各々の試料につき 3 回測定し， 各々の積分值を求め, その平均值をプロットした。

また， 4 種類の血清（No. 18，No. 19，No. 20，No. 21） も同様に処理した後，測定した。 


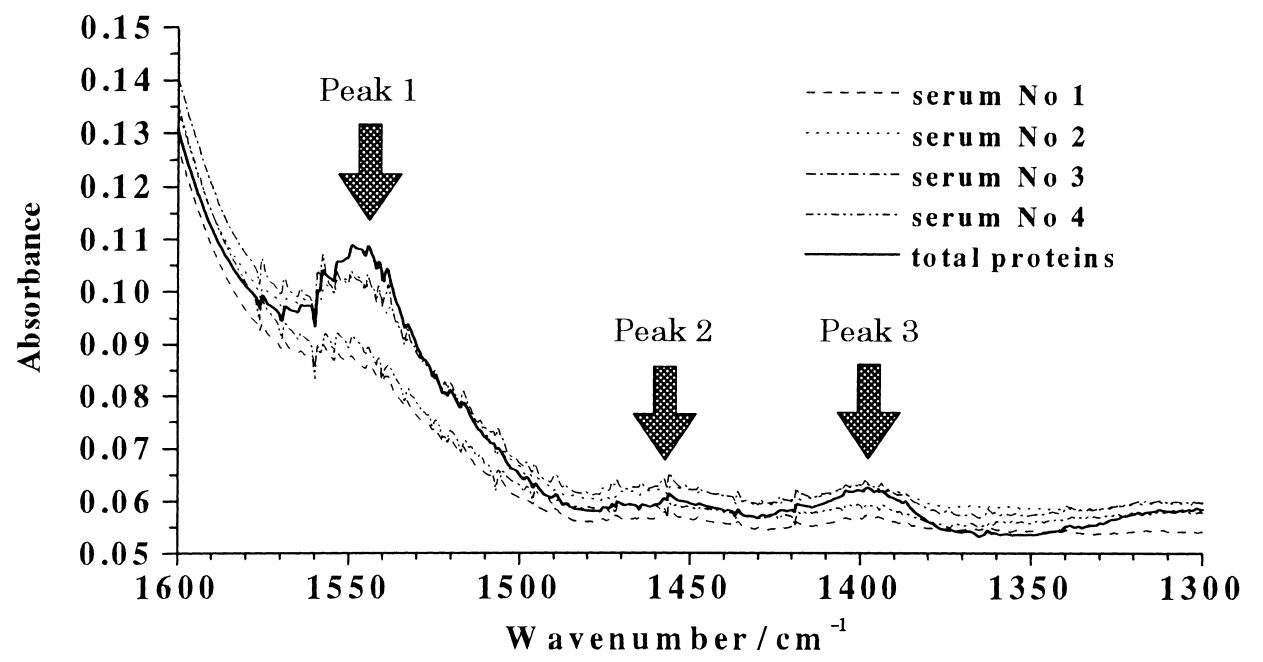

Fig. 1 IR spectra of the serums (No. 1, 2, 3, and 4) and the standard solution of total proteins

\section{3 結果と考察}

\section{$3 \cdot 1 \quad$ 溶液状態での血清中の総タンパク質濃度の定量}

最初に，血清の最大成分であり，グルコースの 50 倍か ら 100 倍の濃度がある総タンパク質の定量を試みた。溶 液状態の血清の赤外吸収スペクトルを測定するとともに, 総タンパク質の標準溶液の赤外吸収スペクトルを測定し, 両者を比較した結果, 血清の赤外吸収スペクトルすべてに おいて, 総タンパク質に由来すると思われる 3 つの吸収 帯, Peak 1，2，3 を確認した（Fig. 1).

これら 3 つの吸収帯のピーク面積と総タンパク質濃度 との相関を調べた. 3 つの吸収帯のうち Peak 2 と Peak 3 は非常に小さな吸収であるために, 血清中の水分に由来す る細かい吸収による影響を無視できないと考え, 測定され た赤外吸収スペクトルをスムージングして，水に由来する 細かい吸収の影響を極力排除した。 ピーク面積は Peak 1 では 1583〜 $1480 \mathrm{~cm}^{-1}$, Peak 2 では $1480 \sim 1428 \mathrm{~cm}^{-1}$, Peak 3 では 1428 ～ $1370 \mathrm{~cm}^{-1}$ の波数領域を積分範囲とし, 2 点ベース法によって求めた積分值を用いた.

それぞれのピーク面積と血清の総タンパク質濃度との相 関は Peak 1，2，3 で各々 $R=0.847 ， 0.754 ， 0.757$ と，一 番大きなピークである Peak 1 の值は比較的良かったが, 残りの二つのピークの值はあまり良くなかった。

その要因としては, 吸収そのものが小さく, 水分に由来 する細かい吸収の影響が取り除けなかったことのほかに, 分光器の解析部の温度と湿度がそれぞれ $30^{\circ} \mathrm{C}$ 以上, $10 \%$ 以下と高温乾燥した状態であるために, 解析中に血清中の 水分の蒸発が進んでしまい, その水分の蒸発の度合いが血 清成分の違いによって大きく異なるためと考えられる.

このように, 最大成分である総タンパク質でも定量は容 易ではなく, 溶液状態の血清の構成成分の定量は困難であ
ることを意味する.

\section{$3 \cdot 2$ 自然乾燥による血清中のグルコース濃度の定量}

グルコース濃度が異なる 4 種類の血清試料の 1140 $950 \mathrm{~cm}^{-1}$ 領域のピーク面積を 2 点ベース法で求め（Fig. 2)，グルコース濃度との相関を調べたところ， $R=0.994$ であった (Fig. 3).この直線を検量線とし，9種類の血清 のピーク面積からグルコース濃度を定量した。それら定量 值と酵素法で求めた值との相関を調べたところ， $R=$ 0.206 と，全く相関が見られなかった（Fig. 4). 検量線の 濃度範囲が実際のサンプルに比べ著しく高いこと，また， この方法ではそのような濃度範囲でしか信頼性のある検量 線を求めることができなかったことが不適切な原因であっ た.また，一つの試料の測定に 5 時間かかるという点に も改善の余地があると考えた。

\section{$3 \cdot 3$ 減圧乾燥による血清中のグルコース濃度の定量}

$3 \cdot 3 \cdot 1$ 溶液ホルダーの新規作製自然乾燥では測定 に約 5 時間を必要とし, 検査方法としての大きなデメリ ットとなっていた。そこで減圧乾燥を試みた。

減圧する際に減圧の度が高すぎると，血清から気泡が発 生してATR プリズムから剥離し, 定量性のない赤外吸収 スペクトルが観測されるので, 減圧度, $20 \mathrm{mmHg}$ で 20 分間，その後 30 分の自然乾燥とした。 また，装置に付属 の溶液ホルダーを用いて減圧乾燥を行うと, 溶液ホルダー 周辺部の斜面の部分からの気化濃縮が優先するために, こ の部分に乾燥した血清が付着してしまい, ATR プリズム 上に十分な量の乾燥血清が確保できず，定量性のある赤外 吸収スペクトルが観測されなかった。 そこで, 円筒形の溶 液ホルダーを作製した。これを用いた結果, ATR プリズ 厶上に十分な量の乾燥血清が確保され，定量的な赤外吸収 


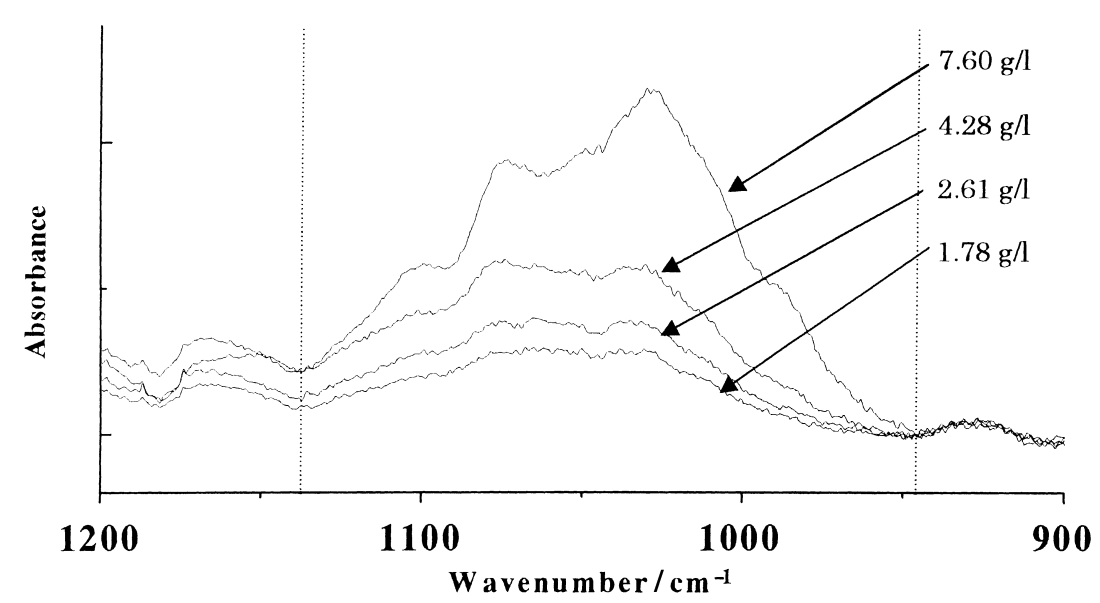

Fig. 2 IR spectra of the dried up samples prepared from No. 5 serum in the presence of the various concentrations of glucose

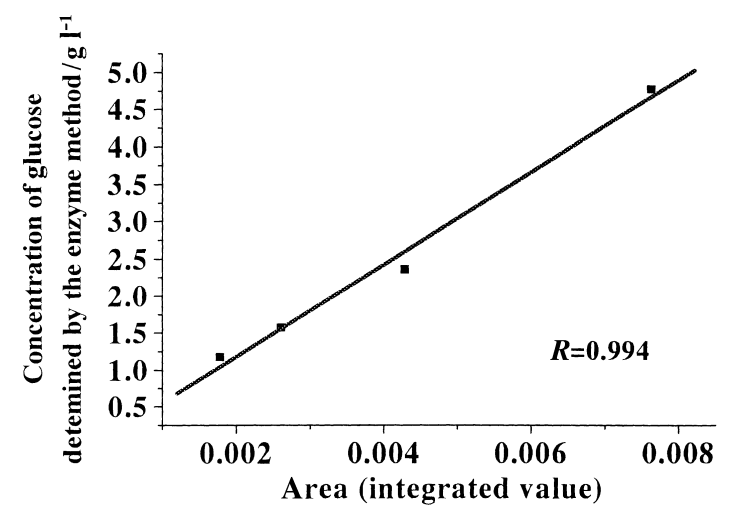

Fig. 3 Correlation between the integrated values of the IR absorptions and the concentrations of glucose, here samples were prepared and dried by the addition of glucose to the serum of No. 5

スペクトルを測定することができた.

$3 \cdot 3 \cdot 2$ グルコース濃度の計算式の作成＼cjkstart次に定量性の 改善のために積分範囲の見直しを行った。これまでグルコ ースに由来する吸収のピーク面積を求めるために積分範囲 として用いた波数領域は $1140 \sim 950 \mathrm{~cm}^{-1}$ と非常に広く, グルコース以外の物質の影響を受けやすいと考えられる。 この波数領域を見直すため, 乾燥血清の赤外吸収スペクト ルを吸収波数の関数として 2 次微分を行った。原スペク トルでは分かりにくい,グルコースに特徵的な吸収帯とさ れる $1030 \mathrm{~cm}^{-1}$ 付近の吸収帯の存在が2)3), 2 次微分スペク トルで確認された（Fig. 5). 波数領域 $1038 \sim 1020 \mathrm{~cm}^{-1}$ を積分範囲として, 2 点ベース法で乾燥血清の原スペクト ルを積分し，その積分值をピーク面積とした。

No. 15 の血清をベースとした濃度の異なるグルコース 溶液を乾燥し, ピーク面積を求め, グルコース濃度に対し

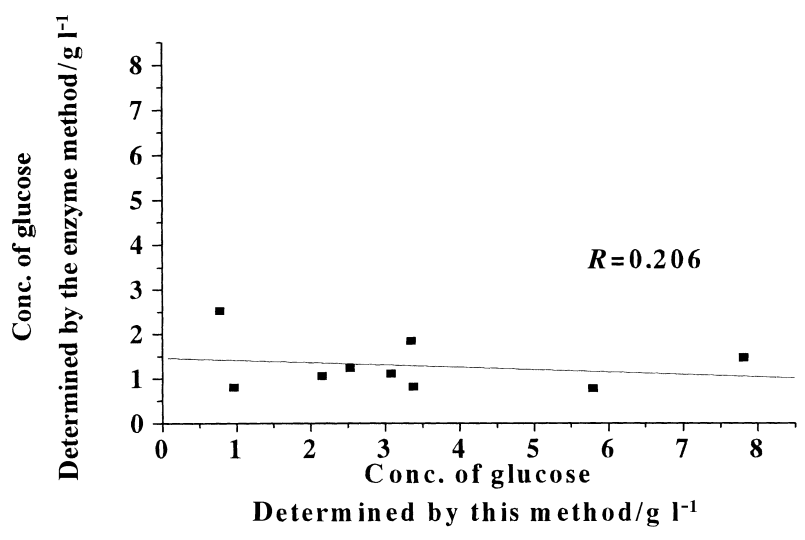

Fig. 4 Correlation between the concentrations of glucose obtained by this IR-ATR method and the conventional method (the enzyme method)

てプロットした。No. 16，17 の血清をベースとして調製 した試料についても同様の操作を行った．血清の組成が大 きく異なるのにもかかわらず，それぞれの試料群では良い 相関を得ることができた（Fig. 6).

3 つの検量線は以下の式で表される.

1）No. 15 の血清を用いた試料群の検量線の式

$$
\begin{aligned}
& {[\text { グルコース濃度 }(\mathrm{g} / \mathrm{l})]=} \\
& \quad 41.4 \times\left[1038 \sim 1020 \mathrm{~cm}^{-1} \text { の積分值 }\right]-2.47
\end{aligned}
$$

2）No. 16 の血清を用いた試料群の検量線の式 $[$ グルコース濃度 $(\mathrm{g} / \mathrm{l})]=$

$$
52.8 \times\left[1038 \sim 1020 \mathrm{~cm}^{-1} \text { の積分值 }\right]-2.47
$$

3）No. 17 の血清を用いた試料群の検量線の式

$$
\begin{aligned}
& {[\text { グルコース濃度 }(\mathrm{g} / \mathrm{l})]=} \\
& \quad 76.1 \times\left[1038 \sim 1020 \mathrm{~cm}^{-1} \text { の積分值 }\right]-3.14
\end{aligned}
$$



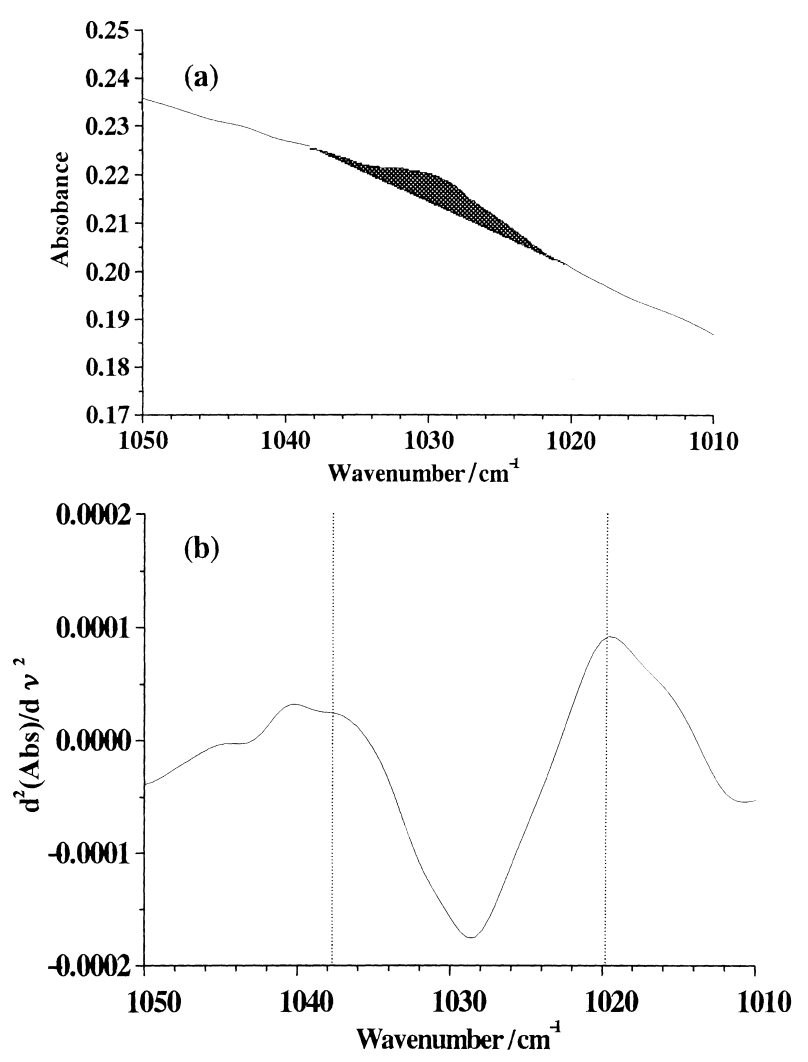

Fig. 5 The original IR spectra with the filled area which was assigned as the absorption (a) and the second ordered differential spectra derived from original spectra (b)

The filled area was decided from the inflexion points of spectra $b$.

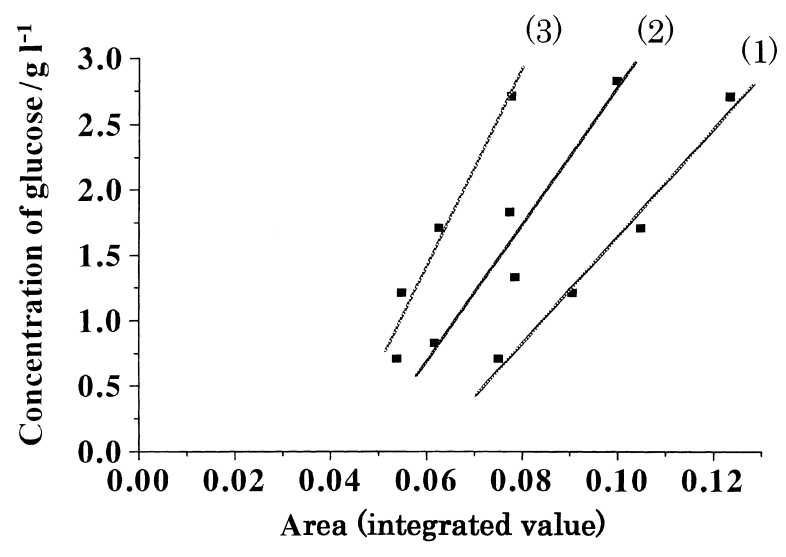

Fig. 6 Correlation between the integrated values of the IR absorptions and the concentrations of glucose The plots (1), (2), and (3), were measured for the vacuum dried samples prepared by the addition of glucose to the serums of No. 15, 16, and 17 , respectively.
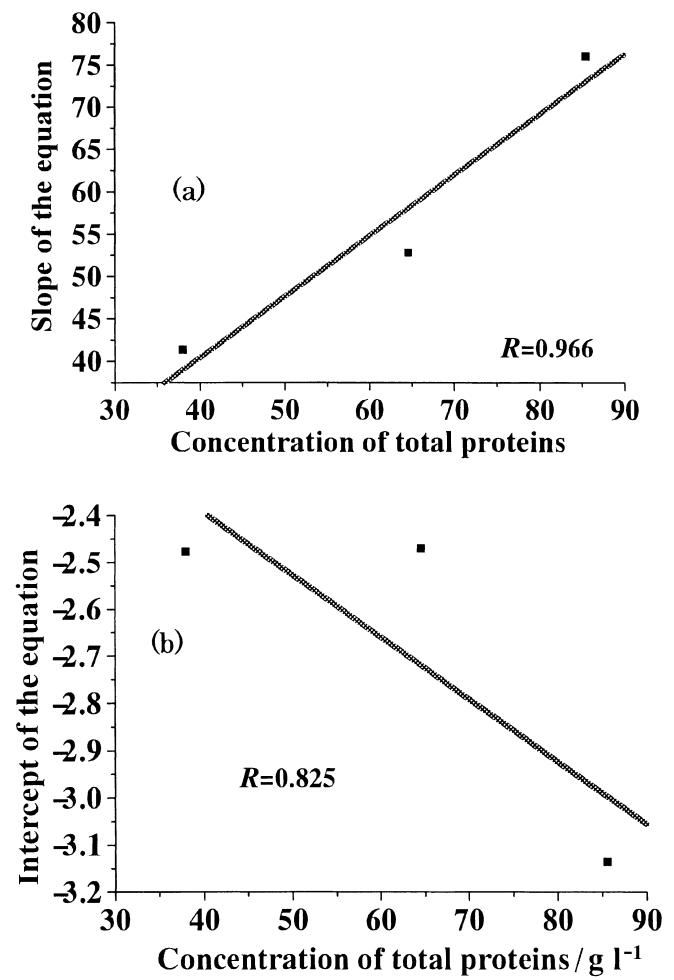

Fig. 7 Correlation between the slopes (a) and the intercepts (b) of the equations 1, 2, and 3 and the total proteins concentrations of the serums of No. 15, 16, and 17 , respectively

3 つの検量線はグルコース濃度以外のなんらかの要因に 影響を受けていることが分かる．2次微分は大きな吸収に 隠れている小さな吸収を検出するのに有効であり，実際に $1038 \sim 1020 \mathrm{~cm}^{-1}$ に存在する吸収はグルコースに由来し ている、しかしながら, 総タンパク質は血清中に最も多く 含まれる物質であり, その濃度はグルコース濃度の数十倍 にもなる，また，タンパク質の一種であるアルブミン（総 タンパク質の中に含まれる）は $1040 \mathrm{~cm}^{-1}$ 付近を中心と した大きな吸収を持っている。以上の理由から総タンパク 質の影響を無視できないと考え，3つの検量線の総夕ンパ ク質濃度に対する依存性を調べた。

3 つの検量線 $\{(1),(2),(3)\}$ の傾きと切片をそれぞ れの試料の総タンパク質濃度（No. 15: $38.0 \mathrm{~g} / 1$, No. 16: $64.6 \mathrm{~g} / 1$, No. 17: $85.6 \mathrm{~g} / \mathrm{l})$ に対して，プロットしたとこ ろ, Fig. 7 のようになった。これら直線の方程式は以下の 式で表される。

1）グルコース濃度の検量線の傾きと総タンパク質濃度 との相関の式

[グルコース濃度の検量線の傾き $]=$

$$
0.716 \times[\text { 総タンパク質濃度 }(\mathrm{g} / \mathrm{l})]-11.9
$$




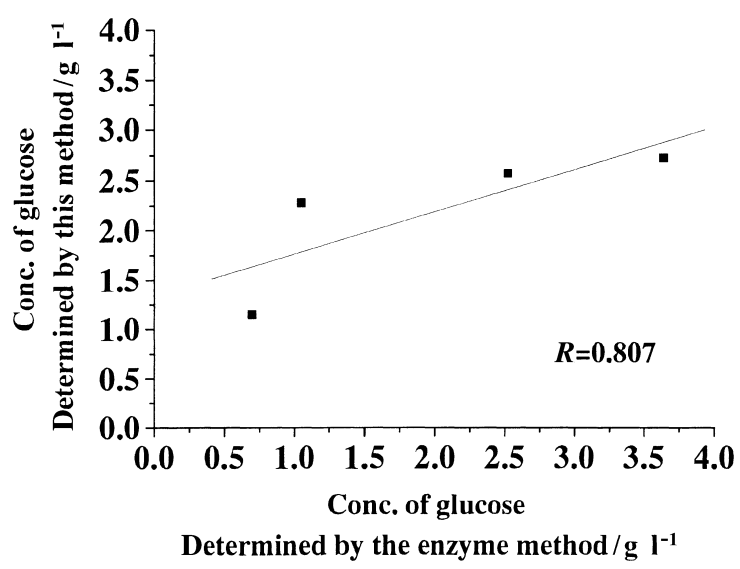

Fig. 8 Correlation between the concentrations of glucose obtained by this refined IR-ATR method and the conventional method (the enzyme method)

2）グルコース濃度の検量線の切片と総タンパク質濃度 との相関の式

[グルコース濃度の検量線の切片 $]=$

$-1.35 \times 10^{-2} \times[$ 総タンパク質濃度 $(\mathrm{g} / \mathrm{l})]-1.85$

式 (1)〜（5） から，1038〜 1020 $\mathrm{cm}^{-1}$ の積分值と総夕 ンパク質濃度を変数としたグルコース濃度を求める計算式 は以下になる。
式（6）に 4 種類の血清（No. 18, No. 19, No. 20, No 21）を乾燥して測定した赤外吸収スペクトルの 1038〜 $1020 \mathrm{~cm}^{-1}$ の積分值と, それぞれの血清の総夕ンパク質濃 度を適用してグルコース濃度を求めた。 得られたグルコー ス濃度と酵素法によるグルコース濃度との相関は Fig. 8 のようになり，相関係数は $R=0.807$ と，相関が見られる 結果を得た。

$$
4 \text { 結 論 }
$$

今回の実験結果によって，赤外吸収スペクトルから血液 中のグルコース濃度を定量できる，という可能性を示すこ とができた。それは，1）ATRサンプルホルダーの形状の 工夫，2）減圧乾燥による測定時間の短縮，3）２次微分に よるグルコース由来の吸収スペクトルの特定，4）総夕ン パク質濃度の影響の考慮，などの改善の結果であり，酵素 法との相関係数 $R=0.807$ という值は, 実用への可能性を 示す值といえる。今後は測定時間の短縮などと併わせてよ り一層の定量性の向上を検討する.

\section{文献}

1) 吉田 敏: 臨床病理, 49, 553, (2001).

2) C. Petibois, V. Rigalleau, A-M. Melin, A. Perromat, G. Cazoria, H. Gin, G. Deleris : Clin. Chem., 45, 1530 (1999).

3) C. Petibois, G. Cazorla, A. Cassaigne, G. Deleris : Clin. Chem., 47, 730 (2001).

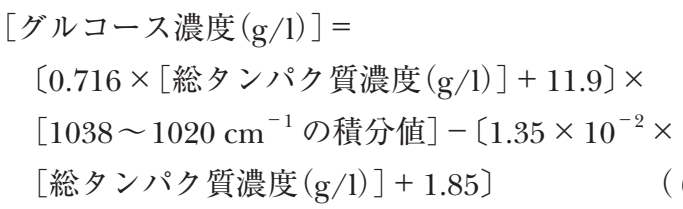

\section{要 旨}

効率的な糖尿病診療のために, 血糖值の簡易な測定方法の開発が求められている. 今回, 全反射型プリズ ムを用いた光学系を用い，フーリエ変換赤外分光法による血清中のグルコースの定量を試みた. 血清は試料 ホルダーに入れ，減圧乾燥した。 その際，定量值の再現性を高めるために試料ホルダーの形状に工夫を加え た. 定量は，グルコース由来の吸収である $1038 \sim 1020 \mathrm{~cm}^{-1}$ 付近の吸収を， 2 点ベース法を用いて行った が，その吸収領域の選定に 2 次微分を用いた。また，吸収強度は総夕ンパク質量に影響されるので，補正 を加えた。これらの改善を加えて定量した結果，本法で求めた值と従来の酵素法により求めた值との相関係 数が, $R=0.807$ となり, 改善前の $R=0.206$ に比べて著しく優れた結果を得ることができた. この結果は, 血糖值の定量に赤外吸収スペクトルを用いることができることを示すものである. 